\title{
The origin of the resurrection idea: A dialogue with George Nickelsburg
}

\author{
P J W (Flip) Schutte (Witbank) ${ }^{1}$ \\ Faculty of Theology \\ University of Pretoria
}

\begin{abstract}
This is a review article on George W E Nickelsburg's book Resurrection, immortality, and eternal life in intertestamental Judaism and early Christianity. The aim of this article is to reflect on the results of Nickelsburg's research with regard to the earliest Christians' understanding of Jesus' resurrection. Nickelsburg investigated the topic of the afterlife in intertestamental Judaism and early Christianity from three perspectives namely, resurrection, immortality, and eternal life. The book focuses on the origins of these perspectives and the dynamics involved in the development of theological understanding of Jesus' resurrection in earliest Christianity. Part one of the article represents the content of Nickelsburg's book, and part two consists of comments debating the results that Nickelsburg puts on the table.
\end{abstract}

\section{INTRODUCTION}

This is actually more than just a review article on George W E Nickelsburg's book Resurrection, immortality, and eternal life in intertestamental Judaism and early Christianity. The aim of this article is in the first instance to introduce the reader to the results of Nickelburg's research on the theme. In his doctoral studies and research for his thesis, he investigated the topic of the afterlife in intertestamental Judaism and early Christianity. In his book he gave attention to the origins of these beliefs and the dynamics involved in their theological development. This article will in part be a representation of the content of his book. However, after the content of his thesis has been shared, one cannot just leave it there without making a few comments. The second part of the

\footnotetext{
${ }^{1}$ Dr P J W (Flip) Schutte (D Litt et Phil, DTh, PhD) participated as research associate in the project "Biblical Theology and Hermeneutics", directed by Dr Andries G van Aarde, Honorary Professor, Faculty of Theology, University of Pretoria. This essay is a review article of George W E Nickelsburg's (2006), Resurrection, immortality, and eternal life in intertestamental Judaism and early Christianity. Cambridge: Harvard Divinity School.
} 
article will be a dialogue with the results that he put on the table. His results will be applied on the Christian interpretation and understanding of the resurrection. The results of this dialogue and debate with Nickelsburg on the interpretation of the topic for Christianity today brought results to the table that post moderns can live with.

\section{NICKELSBURG'S THESIS ON THE ORIGIN OF THE RESURRECTION IDEA}

Resurrection, immortality, and eternal life in intertestamental Judaism and early Christianity is an expanded edition of George W E Nickelsburg's doctoral dissertation, which was first published in 1972. He investigated the theme of the afterlife in intertestamental Judaism and early Christianity from three perspectives: resurrection, immortality, and eternal life. He probed in his investigation attention to the origins of these themes and their theological development in the Hebrew Bible and the texts from the intertestamental period.

The intertestamental period was theologically a brewing period for the doctrine of the afterlife. When Nickelsburg treated the question of resurrection, he also questioned whether it is a reference to a raising of the spirit or the body. He concluded that, by the end of the intertestamental period and the beginning of the Christian movement, the belief in resurrection was clearly that of a bodily resurrection. The book is divided into two major parts. The first part is a reproduction of Nickelsburg's dissertation as it was originally published, with some minor revisions. The second part includes three later studies by the author in which he applied the findings of his dissertation to the New Testament.

\subsection{Part one: The content of his book}

In chapters 1-3 Nickelsburg dealt with the theme of religious persecution. Chapter 1 dealt with apocalyptic texts that have religious persecution as their underlying theme. Among the texts, Nickelsburg (2006:23) analyzed Daniel 12:1-3. He also studied the Testament of Moses ( $p$ 43), Jubilees ( $p$ 47), and the Testament of Judah ( $p$ 49).

On Daniel, Nickelsburg (2006:32) concluded that the theology which the book reflects is that of people whose life situation is one of oppression. The Danielic resurrection belief therefore answered a religious need in the Hasidic community in which the Book of Daniel arose. The political backdrop for the origin of this belief in Daniel was the persecutions of Antiochus and the death of many Hasidic Jews. These deaths presented a theological problem because the Jews who died, were those who were obedient to the Torah. 
Resurrection was the answer to this dilemma. Resurrection either to life (postmortem vindication) or to punishment (post-mortem condemnation).

For Isaiah, according to Nickelsburg (2006:33) the resurrection of the righteous was in itself vindication for the righteous, because only the righteous will be resurrected. For Daniel resurrection was a means by which both the righteous and the wicked dead are enabled to receive their respective vindication or condemnation. Daniel has gone beyond Isaiah in the sense that there will also be punishment for the wicked that are already dead. In Daniel both will be resurrected.

Another important resurrection text in the Hebrew Bible that Nickelsburg (2006:31) could have discussed in more detail is Ezekiel 37 (the vision of the valley of dry bones). Nickelsburg (2006:31) all too quickly dismisses this important text by asserting that, rather than speaking of a resurrection of a people who were literally dead, it rather presents "a picture of the restoration of Israel". While this is true, it is equally true that the use of the metaphor of resurrection itself presupposes an a priori belief and understanding of resurrection as a raising of that which is dead. The metaphor is thus only intelligible and meaningful vis-à-vis the literal word that serves as its reference point.

Nickelsburg (2006:49) made some noteworthy comments on his interpretation of the text in the Testament of Judah. Like Daniel 12 and Jubilees 23 it promised post-mortem vindication for those who have been persecuted because they were righteous. The Testament of Judah 25:4ac and $3 \mathrm{bc}$ states that resurrection is promised to those whose religion has been the cause of their death, that is those who have died in a religious persecution. Those who die such a violent death "die in grief" (25:4). Resurrection is not only another event in the restoration of Israel, as Nickelsburg (2006:51) interpreted Ezekiel 37 . The text state that only certain persons are raised. The choice of some and not others in itself implies a kind of judgment. Moreover, their resurrection is mentioned against the background of a specific circumstance, namely that they died on account of the Lord. Resurrection is thus according to Judah 25 a means of vindicating that pious behavior which was responsible for their death.

To summarize: Daniel awaited a resurrection of the body. Jubilees 23 did not find it necessary to posit a resurrection of the body. The Testament of Judah 25 awaited a resurrection of the body as well as Isaiah 26. Most of these texts can be date between 170 and 160 BCE. Daniel, Jubilees 23 and the Testament of Moses were written in the heat of the persecution. It communicated that the righteous who have died for the Lord will rise, thus post-mortem vindication. 
In chapter 2 Nickelsburg studied the theme of the persecution and exaltation of the righteous person. According to Nickelsburg (2006:67), the thesis of Wisdom of Solomon 1-6 is that unrighteousness leads to death and destruction, while righteousness leads to life and immortality. He examined the theme as it appears in Wisdom 2:4-5 (Nickelsburg 2006:68), including a study of the Gattung in the story of the righteous man found in Wisdom, Genesis 37-45 (the story of Joseph) ( $p$ 68), the Story of Ahikar ( $p$ 69), the book of Esther ( $p$ 70), Daniel 3 and 6 ( $p$ 71), and Susanna ( $p$ 74). Other texts from canonical, apocryphal, and pseudepigraphic collections were also examined. Nickelsburg sees the theme of the persecution and exaltation of the righteous person as fundamental and formative for the development of the belief in resurrection. The theme at this point is focused on an individualistic context: it is the singular righteous person who is persecuted and consequently exalted. The difference between the texts of chapter one and the Wisdom of Solomon is that the latter teached according to Nickelsburg (2006:113) the immortality of the soul rather than resurrection of the body. Regardless of what happens to the bodies of the righteous, their souls are in God's hand and cannot be touched by torment. Different from Daniel 12 and the Testament of Judah 25, here judgment after death did not require a resurrection of the body because, in spite of the destruction of the body, the soul continues to exist and can be judged.

In chapter 3 Nickelsburg carried this theme into a corporate setting with the persecution and vindication of the righteous as a group. Nickelsburg (2006:119) analyzed the text of 2 Maccabees 7 . It is the story of seven brothers and their mother who like the righteous man in Wisdom, were put to death on account of the Torah. As in Wisdom, a rescue after death was anticipated, although here it was not described. The story was also set in the time and in the presence of Antiochus. "The brothers' resurrection will be bodily (7:10-11), and this is appealed to specifically as a remedy for their bodily tortures. God will heal what Antiochus has hurt; he will bring to life whom Antiochus has killed. What God created, God will recreate - in spite of the king's attempt to destroy it (7:22-23, 28-29)" (Nickelsburg 2006:121).

In chapter 4 (Nickelsburg 2006:141), the theme of the oppression of the righteous poor was examined, with special attention given to 1 Enoch 94-104. The historical setting of the situation in Enoch was the same as that of the texts described in the previous chapters. Again it is about the righteous that suffer because of their faithful adherence to the Torah and a post-mortem vindication that awaits them.

In chapter 5 Nickelsburg (2006:163) investigated the theme of resurrection where it appeared unrelated to the themes of persecution, 
oppression, and injustice. In all of these texts (Ps 3; 13; 14; 15; 1 Enoch 22; 4

Ezr 7; Sibylline Oracles 4; The Testament of Benjamin 10), once more, resurrection was set in the context of judgment. There was one new development namely that the "righteous are rewarded because of their obedience to the Torah, even if they have been rewarded during their lives, and although they may not have suffered or died because of their righteousness. The sinners are condemned for their wickedness in general and not specifically because they have maltreated the righteous" (Nickelsburg 2006:177). The scope of resurrection and judgment were thus broadened.

In chapter 6 ( $p$ 179) an analysis was made of the Qumran materials and the "Two-Ways theology." This chapter included an investigation into the view of the afterlife and whether it incorporated resurrection, immortality, or eternal life. Nickelsburg (2006:185) is of the conviction that belief in bodily resurrection appears to be lacking in Qumran. The Qumran texts "make no reference to a persecution unto death that requires a post-mortem vindication. Nor do they speak of injustices and oppression in this life that need to be adjudicated after death" (Nickelsburg 2006:205), but they definitely refer to eternal life.

\subsection{Part two: The three later studies}

In part 2 Nickelsburg dealt with the New Testament. The title of chapter seven is "Resurrection in early Christianity." There Nickelsburg (2006:227) examined belief in the resurrection as found in the early creeds and hymns ( $p$ 228), the Q document ( $p 231$ ), the writings of Paul ( $p 231$ ), including the DeuteroPauline letters ( $p$ 235), the Gospels ( $p$ 236), Hebrews ( $p$ 244), and the book of Revelation ( $p$ 245). Nickelsburg (2006:245) also treated the theme of the persecuted and vindicated servant of the Lord as it is applied to Jesus in the New Testament. Nickelsburg (2006:246), when addressing the Gospel stories about the empty tomb, stated that these stories "presume a bodily resurrection or bodily assumption to heaven." The post-resurrection appearances of Jesus, however, according to him, seemed to militate against this notion. He seemed to strain the arguments concerning the appearances of Jesus by suggesting that the bodily nature of the post-resurrection appearances seemed to conflict with other accounts where the risen Jesus appeared and disappeared at will, his identity is mistaken, he is presumed to be a ghost, and so forth. What the Gospel writers seemed to be communicating was that the risen Jesus was numerically identical but yet dissimilar; in short, the risen Jesus had a changed body. Nickelsburg (2006:247) acknowledged that the genesis of the Christian movement was tied to the very earliest traditions that encompassed belief in the resurrection of Jesus and his exaltation. 
In chapter 8, Nickelsburg (2006:249) presented a study of the genre and function of the Markan passion narrative. According to Nickelsburg (2006:251) the theme of Mark's story is based on the generic model as found in the Joseph narrative (Gn 37-50); the story of Ahikar; the book of Esther; Daniel 3 and 6; Susanna; and, with some qualifications, Wisdom 2:4-5. Mark's passion narrative gleans the themes of the persecution and vindication of the righteous as they are applied to Jesus. Nickelsburg (2006:277) also provided a brief approach to the hypothetical pre-Markan passion narrative with this same theme of persecution and exaltation of the righteous. He concluded that "Mark tells the story of Jesus and the disciples ... he construed his Messiahship in terms of willing death at the hands of those whose existence and authority were bound up with the Temple, and he casted the shape of discipleship in a similar mold. His resurrection had vindicated his teaching, conduct, and his public vindication as Son of Man" (Nickelsburg 2006:277).

In chapter 9 Nickelsburg (2006:281) concluded by addressing the controversial "son of man" title and the function of "the son of man" as it appears in both Judaism and early Christianity. A review of the title was explored in the Hebrew Bible (Nickelsburg 2006:281), as well as the apocryphal ( $p$ 282) and pseudepigraphal writings ( $p$ 288), and how by the intertestamental period we have a composite figure in the preexistent son of man who absorbs the traits of the anointed one, chosen one, Davidic king, and Deutero-Isaiah's servant of the Lord. The groundwork had already been laid for Christianity. Following this, Nickelsburg (2006:293) investigated the use of the "son of man" title in the New Testament and the historical problems of associating this title with Jesus. In the case of Jesus, a conflation took place between two main figures from the Hebrew Bible - the transcendental and heavenly "one like a son of man" (Dn 7:13) and the suffering servant (Is 52-53) - so that Jesus fulfilled both roles.

\section{COMMENTS}

One view that was not mentioned by Nickelsburg and that would have contributed to this study is that of death as the final end to one's existence. This view was held by some intertestamental Jews, as it appears to be attested in Sirach or Ecclesiasticus and was the notable belief of the Jewish sect of the Sadducees, according to Josephus and the New Testament (Mt 22:23; Mk 12:18; Lk 20:27; Ac 23:8).

A second comment is that it appears at times that Nickelsburg confuses resurrection with assumption or translation. When he deals with the text of Jubilees 23, which speaks of the tortured bodies of the righteous resting in the earth while their spirits are assumed into heaven (Nickelsburg 
2006:213), he equates the two terms (Nickelsburg 2006:216). Assumption or translation into heaven could also be bodily, as in the case of Enoch in Genesis 5:24 and Elijah in 2 Kings 2:11, without necessitating death. But these two cases would not be called resurrections. Resurrection, assumption, and translation are thus not synonymous. They have different functions in the narratives in which they appear and they refer to different events.

\section{TAKING NICKELSBURG'S IDEAS FURTHER: THE DIALOGUE}

Taking thus the findings of Nickelsburg's study on the origin of the themes: resurrection; immortality; and afterlife, as concepts that originated in the persecution situation of the intertestamental period further, it thus seems to me that according to his findings it was not Jesus who through his death and resurrection made eternal life and resurrection possible, as orthodox dogma states. Resurrection must rather be seen as a theological construct in the intertestamental period to make life bearable under difficult circumstances.

The question to answer then, when it comes to Jesus-studies is: Why did early Christians proclaim "God raised Jesus from the dead"? The most obvious answer might be that they had heard stories about the resurrection. Still there is not a single story of the resurrection in all of early Christianity, except for a late story in the Gospel of Peter 10:38-11:43 (Crossan 1996:202). The resurrection itself is never described - which leaves Patterson (1998:218) to conclude that "(I)eaving aside any theological point to be made from this, historically we can say with confidence that such stories were clearly not the basis of the early Christian claim that God had raised Jesus from the dead, because, so far as we know, there are none."

\subsection{Appearance stories}

What we do have in abundance are the appearance stories, from which the resurrection might have been inferred. A number of people not only believed they had seen the Lord; they had experienced seeing the risen Lord (Dunn 2003:861). However, the resurrection and appearance stories are not usually presented in tandem. "In this respect 1 Corinthians 15:3-8 is somewhat misleading in its explicit use of the appearance tradition to reinforce belief in the resurrection. Paul does this under the extraordinary circumstance of needing to present an overwhelming argument for the resurrection of Jesus, and then only in the service of his larger aim to convince the Corinthians of his belief in the general resurrection of the dead. Even here, Paul shows that such an argument is precariously constructed when he reverts to the only real basis for his claim in verse 11: "so we preached and so you believed". For 
Paul there is no real proof of the resurrection claim, except the active faith of the communities that are themselves the "body of Christ" (Patterson 1998:219). Nowhere does Paul mention an empty tomb. The appearance stories are not normally used in the tradition to prove that the resurrection is true. They are in Paul, Matthew, Luke, and even in John, presented as a sign of commissioning to preach the gospel.

The earliest simple resurrection formula does not presuppose the appearance tradition. Together with Patterson (1998:219), I believe that "(r)ather, it is quite the opposite: the appearance tradition, with its orientation to the commissioning of disciples to preach, presupposes the resurrection tradition. After all, before anyone could be commissioned to preach, there had to be a gospel to preach."

The content of the gospel is that Jesus, who had been crucified, was raised from the dead by God. The resurrection tradition has priority over the appearance tradition. In this sense, it is very unlikely that the resurrection proclamation arose in response to stories of Jesus' appearance.

\subsection{The resurrection claim}

What, then, was the basis for the early Christian claim that God raised Jesus from the dead? The answer lies in the nature of the resurrection claim itself (Patterson 1998:220):

In Jewish tradition, the idea that God would raise someone from the dead arose when the Jews faced the disturbing reality that just and righteous people are sometimes killed at the hands of their foes, as Nickelsburg has proven in his study. In Isaiah 24-27, the prophetic voice utters a protest against the demise of faithful Jews (Nickelsburg 2006:33): All who have died for Yahweh's sake shall someday be restored. In Daniel 12:1-3 the context is again martyrological as is the case in writings such as 1 Enoch 22-27, 1 Enoch 92-105, Jubilees 23:11-31, 2 Maccabees 7, 4 Maccabees 7:3; 9:22; 13:17 et al, Wisdom of Solomon 1-6, 2 Baruch 49-51, and 4 Ezra 7. Whether a strict concept of resurrection is embraced, or, as in some of the later of these texts, something like redemption of immortal souls is implied - in this great variety of expressions the fundamental existential concern is always the same: What happens to just and righteous people, treated unfairly by a world full of injustice?

So, the presupposition for any claim about resurrection is not appearance stories or empty tombs. Resurrection, as vindication, presupposes only that a righteous person has been killed in faithfulness to a divine cause. In a dissident Jewish context, this is all you need. The followers of Jesus could have said "God raised Jesus from the dead" on the day he 
died, and probably did. The only necessary presupposition for such a statement is the conviction that, should Jesus be killed, God would raise him from the dead. This conviction is one which Jesus' followers would have had the minute they decided that he was right about who God was, and began to participate in the imperial rule of the God that he proclaimed. Resurrection is the vindication of a life lost to the forces of injustice in the world. To the extent that Jesus' followers embraced his life as God's own work, the resurrection proclamation would have arisen quite naturally as the appropriate Jewish response to his untimely death (Patterson 1998:220).

Paul's belief in the resurrection of the dead had been part and parcel of his Israelite anthropology prior to his coming to faith in Jesus Christ (Pelser 1986:39). The second of the Eighteen Benedictions in the traditional Jewish liturgy says: "Blessed are you Yahweh, who makes the dead to live." This is not far from the simple early Christian benediction formula, "God, who raised Jesus from the dead" (Lüdemann 1994:25), which Paul uses in Romans 4:17 and which formed part of the early Christians' worship liturgy.

After Jesus' death, his followers would probably have continued their practice of gathering, probably around a meal, to speak of what they had heard and experienced in the company of Jesus. In this context of Christian worship, prayers would have been uttered in the traditional Israelite way. Amongst them, one certainly would have been something like "Blessed are you, Yahweh, who raised Jesus from the dead." They would have said this because they believed that Jesus had died for a divine cause. Later, they even might have sung a hymn, whose middle verses went something like this (Phlp 2:6):
And being in human form, he humbled himself
and became obedient until death, death by crucifixion.
Therefore, God has highly exalted him, and given him the name that is above every name (...)
(...) Lord Jesus Christ (...)

In this familiar pre-Pauline hymn even with its bold Christological claims, empty tombs and appearances are nowhere mentioned. Jesus goes directly from crucifixion to heavenly exaltation, and the only prerequisite for this claim is "obedience" until death (Patterson 1998:221). Reflection on the death by crucifixion and the resurrection as a vindication of the martyr is no longer the primary interest. According to the Christ myth, Jesus became Christ because of his obedience unto death and here in the hymn, Jesus is the incarnation of a divine figure who possessed, already at the very beginning, equality with 
God and who had every opportunity to be Lord simply by taking possession of his kingdom. He did not grasp that opportunity but took the position of an obedient slave. Because of this, God exalted him to an even higher lordship (Mack 1995:92). Instead of a martyrology, the early Christians now had a myth of cosmic destiny in their hands. Thus, the poem is not really about Christ; it is a hymn about Jesus Christ as Lord - the Lord above every other lord.

In the cultural turmoil of the Graeco-Roman age, even the gods had to compete, and in order to outrank other deities, extravagant claims had to be made. Therefore the Christ hymn does not contain thoughts that others would have found strange or outlandish per se, if they were claims made in the name of a known god. The audacity, rather, was to think of Jesus as such a god in the first place. To make such claims for Jesus the martyr would certainly have turned some heads. So we need to ask what caused the thought that Jesus had been or was a god (Mack 1995:93).

\subsection{The background of the "Christ myth"}

Clues pertaining to this belief are available in the three myths that form the background of this poem. The first of these is the story of wisdom's child who is rescued from powers that imprisoned it. Jesus had knowledge that only a divine man could have. In the original "Christ myth", a merger of the wisdom tale and martyrology suggests the thought that Jesus had been faithful to his teachings and to God and was thus vindicated by being raised from the dead. In the poem, he is exalted to a position of sovereignty after his death. The second myth is a romantic picture about the ideal king or ruler. According to this myth, the ideal ruler would not take advantage of his godly appearance and power, but would put it aside in order to serve the interest of the people. The third myth is a myth common to most cultures of the time, namely that the gods would descend from heaven, appear as messengers, and then return to heaven (Mack 1995:93). There is also the possibility that the book of Isaiah may have been the fourth source for some of the imagery of the Christ hymn. The suffering servant depicted in Isaiah 52 was humiliated, killed and exalted. This is also discussed by Nickelsburg (2006:83). In addition, there is also the claim made by God himself in Isaiah 45 of "every knee bowing" and "every tongue swearing." Jesus was given a place higher than that of the other rulers, and his domain was imagined to be larger. The result was that Jesus' position of authority now encompassed all the kingdoms imaginable within a single cosmic horizon and therefore Jesus Christ could be celebrated and glorified as Lord of all (Mack 1998:94). 
The resurrection tradition is an exegetical tradition rather than something that was linked to the appearance tradition. For Paul (1 Cor 15:3-4) the resurrection was true because it happened according to the Scriptures. As much as we might like to think of the resurrection of Jesus as a unique event, which separates Christians even from their Jewish roots, this does not do justice to the origin of the resurrection proclamation itself. According to Nickelsburg the kerygma of the resurrection has its origin in the persecution during the late Biblical and intertestamental era.

\subsection{The uniqueness of the proclamation}

To refer to Patterson (1998:222) once more: "When this proclamation is examined carefully as it appears in early Christian tradition, we can see that this most central claim of Christian faith is a response to the life and death of Jesus that is quite understandable within the culture of ancient Judaism." Every ancient resurrection claim is distinctive in some respect and has its own innovation (Crossan 1996:189). One of the distinctive things about Christian resurrection claims has to do with timing. In most Israelite scenarios of vindication, resurrection is regarded as a future event involving all of God's faithful ones at some climactic point in history, as Nickelsburg has shown in his study. In his work entitled The God of Jesus, Patterson (1998:222) describes this viewpoint as follows:

[M]any Christians spoke of Jesus' resurrection as a past event, involving only him. For some early Christians, like Paul, this could only mean that the end had come and that Jesus was but the "first fruits" of many others who would also soon be raised (1 Cor 15:2028). However, even this idea cannot be said to be uniquely Christian. In the broader Hellenistic world, it was commonplace to speak of great heroic individuals who had been taken up to dwell amongst the gods as a reward for and the vindication of a life well lived. This tradition, too, would have been influential in the Hellenised Jewish environment of the first century, and it no doubt influenced the formulation of early Christian claims about Jesus.

\subsection{Post-resurrection appearances}

To comment on the issue of the post-resurrection appearances as mentioned by Nickelsburg in chapter seven of his book, I would like to contribute the following thesis: Soon after his crucifixion, according to the narratives, Jesus appeared to some individuals. However, the earliest appearance did not take place at the tomb, since the tradition of the tomb and the tradition of Jesus' appearance did not originally belonged together (Lüdemann 1995:79). The appearance tradition is a tradition on its own with its own formal features as 
well as setting in the life of the early Christians, distinct from the empty-tomb tradition. The correlation of these traditions in terms of resurrection rationale is evident, but the correlation of their tradition history is less clear (Dunn 2003:864). In tradition-historical terms the probability is strong that the tradition of the empty tomb, including its discovery "on the first day of the week", goes back to claims made by the women.

In the case of the resurrection-appearance tradition we nevertheless rely on what we can glean from the traditions themselves. Paul's personal testimony is crucial in this respect (Dunn 2003:864). All the references we have to the appearance tradition are associated in some way to the commissioning of the apostles to preach. This suggests the context of mission activity as its place of origin (Patterson 1998:223). Take Paul for example: Only through the appearance of the risen Christ to him on his way to Damascus was he entrusted with the mission to the Gentiles, having his actions legitimated once and for all (Lüdemann1995:102). In other words: Jesus' appearance sanctioned Paul's mission, by giving him the same authority to be an apostle as that of the Twelve.

What makes the tradition more complex, though, is the claim that God revealed the risen Jesus to certain living historical persons. Some of the first believers experienced "resurrection appearances" and those experiences are enshrined, as with the earlier impact made by Jesus' teaching and actions, in the traditions which have been handed down to us (Dunn 2003:862). One such person, Paul, is speaking in 1 Corinthians 15:8 and he claims to have experienced the risen Jesus (1 Cor 9:1). The question that this tradition poses is whether Paul and the others in fact had experiences which they took to be appearances of the risen Jesus. It is important to note that they all proclaimed the resurrection but did not experience it (Marxsen 1975:81). Their experience is described as seeing Jesus. Both Jerusalem and Galilee are mentioned as scenes of the appearance of Jesus after his death. Had the first appearances taken place in Jerusalem, it would be impossible to explain to those in Galilee why the disciples had gone back to Galilee after their resurrection experience. The earliest community, after all, was in Jerusalem. For this reason, it is also difficult to imagine how anyone could have invented Galilee as the place where Jesus appeared.

Therefore, it seems most probable that the first appearance experience indeed took place in Galilee and that subsequent ones followed in Jerusalem. However, that makes it impossible for these appearances to have happened on the third day after the crucifixion, because the disciples could not have returned from Jerusalem to Galilee in the period from Friday to Sunday with the Sabbath in between. In the earliest mention of these events in 1 
Corinthians $15: 4$, only the resurrection of Jesus and not his appearance, is dated to the third day.

Mary of Magdala claimed to have been the first to have experienced an appearance of the risen Jesus. This was according to Funk and the Jesus Seminar (1998:479) probably the case (see Mk 16:1, 9; Mt 28:1; Lk 24:10; Jn 20:1; Gospel of Peter 12:50; Epistula Apostolorum 9). It seems Paul believed Peter in that he was actually the first to have seen Jesus (cf 1 Cor 15:5), although Peter himself and the other "pillars of faith" fled during the turmoil surrounding Jesus' crucifixion (Mk 14:50). Peter claimed to have received the first vision, which is to be interpreted psychologically as the result of severe emotional anguish and the overcoming of a severe guilt complex (Lüdemann 1995:129). He had sinned against Jesus by denying him. However, under the impact of the preaching and death of Jesus, and through an "appearance" of the risen Christ, Peter claimed God's forgiveness. This first vision became the spark for a further series of visions to take place.

Paul's appearance did not depend on Peter's vision, since he was not a follower of Jesus, but an enemy. However, as seen above, his appearance served as a confirmation for his apostleship, leadership, and his mission amongst the Gentiles; therefore God must no longer be assumed to be the author of the visions, because there were other motives behind reporting them (Lüdemann 1995:130). We must say farewell to the idea that the resurrection of Jesus was a historical event, or that it happened with divine intervention. There are other explanations for the origin of the tradition, and there are other motives for claiming that Jesus appeared to some.

\subsection{Conclusion}

The answer to the questions concerning the resurrection, how the tradition began and what it meant to those who cultivated and guarded it, lies not in the gospel stories about Jesus rising up out of the tomb, to quote Patterson (1998:237), "as a flesh-and-bones, walking, talking corpse. Rather, we come closer to the truth when we look carefully at the much earlier tradition about Jesus' resurrection and appearances that Paul uses in 1 Cor 15:3-8."

It is learnt from these traditions that the belief in the resurrection of Jesus began as an act of proclamation. Jesus' followers were convinced that God would raise Jesus from the dead, because Jesus had been right about God - and because he was right about God, he should not have been killed, and therefore would be risen from the dead (Lüdemann 1995:132). This connects Christian faith to the Israelite context of martyrology and the Jewish reflections on resurrection as Nickelsburg has indicated in his book. Therefore, one can conclude that it was not necessary for Christians to have 
had experiences of the risen Jesus, or to have discovered the empty tomb. Their belief in the resurrection of Jesus had its origin in the conviction that Jesus had been right about God.

The early Christians were also a religious movement alive with spiritual enthusiasm, and leaders such as Paul, Peter, James and John claimed that they had had ecstatic revelatory experiences. Because they believed that God would raise - and had raised - Jesus from the dead, such experiences could be interpreted and understood as appearances of the risen Jesus (Crossan 1996:203). Patterson interpreted the appearances as follows:

\begin{abstract}
Since these experiences were also taken as signs that those who had received them had been commissioned to preach the good news, the Christians gradually came to attribute such experiences to groups, such as "the Twelve", or "the apostles", as a formal way of recognizing their authority to preach. Finally, there were manifestations of spiritual enthusiasm in early Christian worship. This, too, came to be understood as the presence of the living spirit of Jesus amongst those gathered at such events.
\end{abstract}

(Patterson 1998:238)

The early Christians interpreted Jesus' life on earth and consequent resurrection from death as God's breaking into history to redeem mankind from its demonic rebellion against God. For the Christian faith, Jesus' life did not end on Golgotha - and precisely here lies the decision of Christian faith. It is not a decision about miracles, empty tombs and risen corpses, but a decision about Jesus himself. Was Jesus right about God or not?

For Christian faith to be faith (myth), this decision or risk to believe in Jesus must be embraced without fear. To insist that the resurrection was a historical event and to embrace as true only that which can be proven historically or scientifically, is not faith.

The earliest Christians understood the resurrection of Jesus as a challenge to believe that history is not all there is to human existence. For them, the resurrection was a call to have faith that we live in the presence of God, whose gracious and loving character shone forth in the life of Jesus of Nazareth. They understood it as an invitation to live life as a faithful, trusting response to God, extending that experience of gracious love to others, just as God had extended it to them in the ministry of Jesus. This challenge, call and invitation are still ours today (Patterson 1998:239).

Resurrection is, theologically speaking, not about the resuscitation of a corpse but about the resuscitation of hope against all odds that there is indeed 
a God that loves us. This is the God Christians claim to have met in the life and preaching of Jesus of Nazareth. The earliest Christians truly believed that Jesus was right. They believed it before his death. That is why they proclaimed the resurrection in the first place: For them, the resurrection depends on whether or not Jesus was right about God - and they believed that he was. There was something in what the first witnesses saw and believed that they could express only as "resurrection". There seems to have been something about these Easter experiences which, in a determining and decisive way, impacted in the affirmation, "God has raised Jesus from the dead!" (Dunn 2003:874).

Jesus' resurrection is thus also a post-mortem vindication. He was right about God, suffered unjustly and died as a martyr. The theology of resurrection, as indicated by Nickelsburg, is a construct developed in the intertestamental period to give hope in difficult times. This same construct is applied by the early Christians in their theology. That gave birth to their belief in the resurrection of Jesus. That gave them hope! Resurrection is thus about justification, vindication, and hope.

\section{Works Consulted}

Crossan, J D 1996. Who killed Jesus? New York: HarperSanFrancisco.

Dunn, J D G 2003. Jesus remembered: Christianity in the making, Vol 1. Grand Rapids, Ml: Eerdmans.

Funk, R W \& The Jesus Seminar 1998. The acts of Jesus: The search for the authentic deeds of Jesus. New York: HarperCollins.

Lüdemann, G 1994. The resurrection of Jesus: History, experience, theology Minneapolis, MN: Fortress.

Mack, B L 1995. Who wrote the New Testament?: The making of the Christian myth. San Francisco, CA: HarperSanFrancisco.

Marxsen, W 1975. The resurrection of Jesus of Nazareth, $4^{\text {th }}$ ed. Philadelphia, PA: Fortress.

Nickelsburg, G W E 2006. Resurrection, immortality, and eternal life in intertestamental Judaism and early Christianity. Cambridge: Harvard Divinity School.

Patterson, S J 1998. The God of Jesus: The historical Jesus \& the search for meaning. Harrisburg, PA: Trinity Press International.

Pelser, G M M 1986. Resurrection and eschatology in Paul's letters. Neotestamentica 20, 37-46. 